\title{
Impact of early chimerism status on clinical outcome in children with acute lymphoblastic leukaemia after haematopoietic stem cell transplantation
}

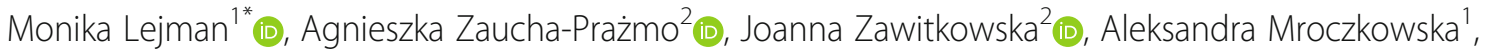
Dominik Grabowski ${ }^{2}$, Jerzy R. Kowalczyk² ${ }^{2}$ and Katarzyna Drabko²

\begin{abstract}
Background: The significance of very early chimerism assessment before day +28 , which is considered the moment of engraftment, is still unclear. In this retrospective study, we evaluated the clinical impact of very early chimerism on the clinical outcome after allogeneic haematopoietic stem cell transplantation (allo-HSCT) in children with acute lymphoblastic leukaemia (ALL).

Methods: The study group included 38 boys and 18 girls. Very early chimerism was evaluated on days $+7,+14,+21$ and +28 after the transplant. Short tandem repeat polymerase chain reaction (STR PCR) was used to analyse chimerism.

Results: Overall survival (OS) and event-free survival (EFS) were 84 and $80 \%$, respectively. The OS in the group of 24 patients with complete donor chimerism on day +14 was $83 \%$, and it did not differ statistically compared to the 32 patients with mixed chimerism on day + 14 (OS was 84\%). In our cohort of patients, the matched unrelated donor, male gender of donor, number of transplanted cells above $4.47 \times 10^{6} \mathrm{~kg}$ and no serotherapy with anti-thymocyte globulin (ATG) were statistically related to a higher level of donor chimerism. The immunophenotypes of disease, age of patient at time HSCT, recipient sex, stem cell source (peripheral blood/bone marrow) and conditioning regimen had no impact on early chimerism. Acute graft versus host disease grades II-IV was diagnosed in 23 patients who presented with donor chimerism levels above $60 \%$ on day 7.
\end{abstract}

Conclusions: The data presented in this study provide valuable insight into the analysis of very early chimerism in children with ALL treated with HSCT.

Keywords: Chimerism, Engraftment, Quantitative PCR, GvHD, Acute lymphoblastic leukaemia, Allogeneic Haematopoietic stem cell transplantation

\section{Background}

Current chemotherapy regimens for acute lymphoblastic leukaemia (ALL) result in a remission in the majority of children with the disease. Despite remarkable improvement in the treatment of this malignancy, $20 \%$ of children still relapse, and their outcome remains poor [1]. Allogeneic haematopoietic stem cell transplantation (allo-HSCT)

\footnotetext{
* Correspondence: lejmanm@poczta.onet.pl

${ }^{1}$ Laboratory of Genetic Diagnostics, Department of Pediatric Hematology, Oncology, and Transplantology, Medical University of Lublin, A. Gebali 6, 20-093 Lublin, Poland

Full list of author information is available at the end of the article
}

for these children has become a well-established treatment to control the disease [2]. The curative effect of allogeneic HSCT for acute leukaemia is attributed to the graft versus leukaemia effect produced by allogeneic immune cells, as well as intensive conditioning chemotherapy with or without radiotherapy [3].

It is well known that chimerism monitoring is an important diagnostic tool for assessing the risk of relapse after allo-HSCT in patients with malignant diseases, especially in those, who lack specific markers for tracking residual disease [4]. However, the significance of very early chimerism assessment before day +28 , which is 
considered the moment of the engraftment, is still unclear. The studies show that early analysis of $\mathrm{T}$ - and NK-cell chimerism can therefore be instrumental in risk assessment and therapeutic management of imminent graft rejection [5].

Investigations on the new methods for routine chimerism monitoring are very promising; however, the current gold standard method of monitoring chimerism is short tandem repeat polymerase chain reaction (STR PCR), which not only determines the type of chimeras, but also determines the percentage of both donor and recipient cells [6-8]. The persistence or reappearance of recipient cells after allo-HSCT can indicate the presence of malignant cells or the recurrence of the recipient's haematopoietic cells or a combination of both [9].

The aim of this study was to analyse the dynamics of early chimerism after allogeneic HSCT in children with ALL and its role in the assessment of survival and eventfree survival. Furthermore, this study analyses the evolution of chimerism over time and evaluates the impact of transplant variables on chimerism.

\section{Methods}

\section{Patients}

The research encompassed biological material (peripheral blood) derived from 56 consecutive children diagnosed with acute lymphoblastic leukaemia who had undergone allogeneic haematopoietic stem cell transplantation at the Department of Paediatric Haematology, Oncology and Transplantology of Medical University in Lublin between 2002 and 2018. The patients' characteristics are summarized in Table 1.

All patients were conditioned according to the European Bone Marrow Transplantation (EBMT) guidelines [10]. Conditioning was myeloablative (MAC), and standard regimens were based on fractionated total body irradiation (FTBI) or busulfan. In reduced toxicity conditioning (RTC), treosulfan was used instead of busulfan. Cyclosporine was used as a graft versus host disease (GvHD) prophylaxis. Matched unrelated transplant recipients received anti-thymocyte globulin (ATG) to prevent GvHD. Mismatched related transplant recipients received ex-vivo T-cell depleted grafts. Engraftment was diagnosed when an absolute neutrophil count (ANC) of 500 or more was observed for 2 days.

\section{Chimerism analysis}

Very early chimerism was evaluated from peripheral blood (PB) on days $+7,+14,+21$ and +28 . Next, samples were collected, and chimerism was monitored according to the EBMT guidelines as a part of the routine follow-up post allo-HSCT $[9,10]$. Depending on clinical indications, chimerism was monitored irrespective of the scheduled time points. A previously described STR PCR
Table 1 Characteristics of patients and transplantation

\begin{tabular}{|c|c|}
\hline & Patients $n=56(100 \%)$ \\
\hline \multicolumn{2}{|l|}{ Immunophenotype } \\
\hline B ALL & $31(55 \%)$ \\
\hline TALL & $25(45 \%)$ \\
\hline $1 \mathrm{CR}$ & $26(46 \%)$ \\
\hline$>2 \mathrm{CR}$ & $30(54 \%)$ \\
\hline Median age at transplant (range) years & $9,04(1,72-17)$ \\
\hline \multicolumn{2}{|l|}{ Patient gender } \\
\hline Male & $38(68 \%)$ \\
\hline Female & $18(32 \%)$ \\
\hline \multicolumn{2}{|l|}{ Donor type } \\
\hline Matched related & $25(45 \%)$ \\
\hline Matched unrelated & $28(50 \%)$ \\
\hline Mismatched related & $3(5 \%)$ \\
\hline \multicolumn{2}{|l|}{ Donor gender } \\
\hline Male & $31(55 \%)$ \\
\hline Female & $25(45 \%)$ \\
\hline \multicolumn{2}{|l|}{ Stem cell source } \\
\hline Bone marrow & $47(84 \%)$ \\
\hline Peripheral blood & $9(16 \%)$ \\
\hline \multicolumn{2}{|l|}{ Conditioning regimen } \\
\hline Radiation-base & $41(73 \%)$ \\
\hline Busulfan-based & $2(3 \%)$ \\
\hline Reduced toxicity & $13(24 \%)$ \\
\hline \multicolumn{2}{|l|}{ Serotherapy (ATG) } \\
\hline YES & $28(50 \%)$ \\
\hline NO & $28(50 \%)$ \\
\hline \multicolumn{2}{|c|}{ Number of CD34+ cells (median 4,47) range $\left(2-13,3 \times 10^{6} / \mathrm{kg}\right)$} \\
\hline$<4,47 \times 10^{6}$ & $35(62 \%)$ \\
\hline$>4,47 \times 10^{6}$ & $21(38 \%)$ \\
\hline $\mathrm{aGvHD}$ & $23(41 \%)$ \\
\hline cGvHD & $4(7 \%)$ \\
\hline
\end{tabular}

$B$ ALL B-cell acute lymphoblastic leukaemia, $T$ ALL T-cell acute lymphoblastic leukaemia, $C R$ complete remission, ATG Antithymocyte globulin, aGvHD Acute Graft Versus Host Disease, $C$ GvHD Chronic Graft Versus Host Disease

method that has been standardized in our laboratory based on Eurochimerism recommendations was used for chimerism assessment $[11,12]$. The sensitivity of our method for detecting recipient cells was $1 \%$, but patients with verified $1 \%$ autologous cells in 2 repeated samples were considered mixed chimeras. Early mixed chimerism was determined as the presence of $1 \%$ or more recipient cells in peripheral blood.

The genomic DNA was isolated from mononuclear peripheral blood cells. Peripheral blood was aspirated into anticoagulant (EDTA)-containing tubes. The isolation of the mononuclear cell (MNC) fraction was 


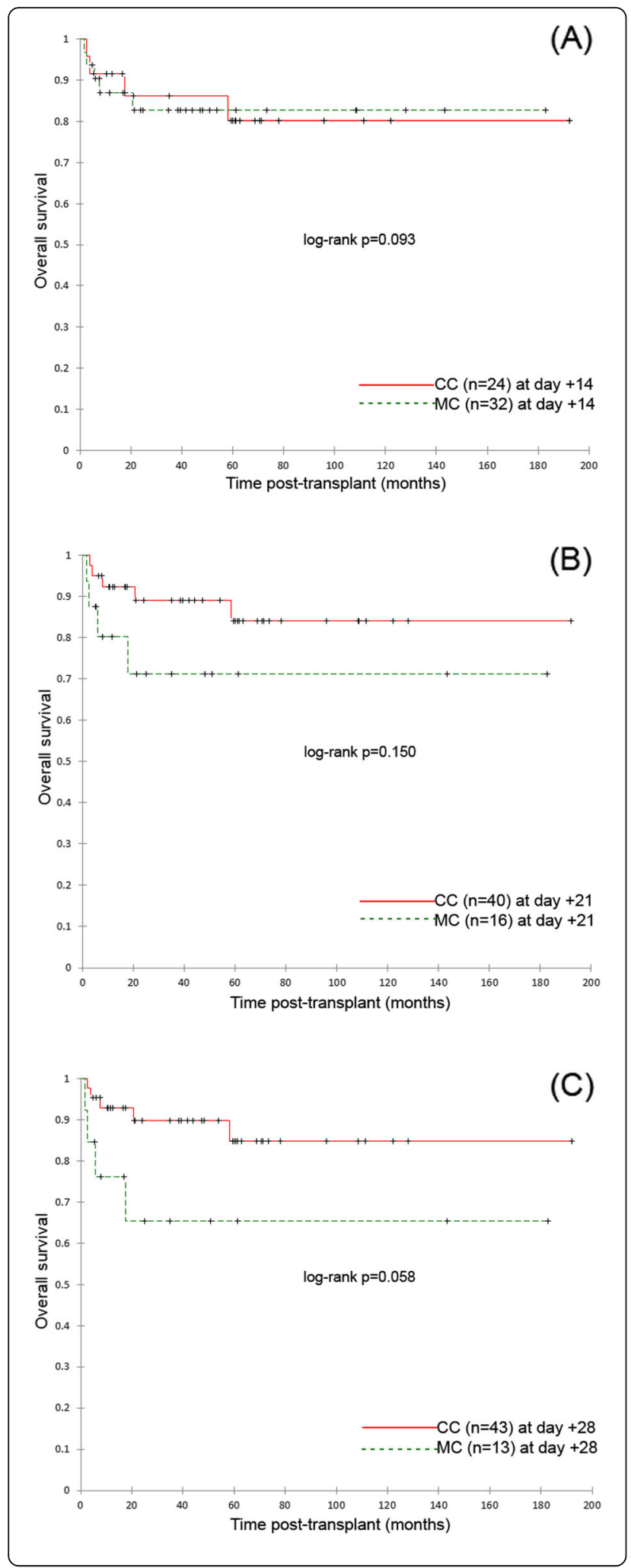

Fig. 1 Overall survive (OS) of study patients. a Kaplan-Meier survival plots for OS of study patients with complete donor chimerism $(n=$ 24) in day 14 and patients with mixed chimerism $(n=32)$ in day 14. Study cohort: $n=56, p=0.093$. b Kaplan-Meier survival plots for OS of study patients with complete donor chimerism $(n=40)$ in day 21 and patients with mixed chimerism $(n=16)$ in day 21. Study cohort: $n=56, p=0.150$. c Kaplan-Meier survival plots for OS of study patients with complete donor chimerism $(n=43)$ in day 28 and patients with mixed chimerism $(n=13)$ in day 28 . Study cohort: $n=56, p=0.058$

performed using Ficoll-Paque PLUS aqueous solution of $1.077+0.001 \mathrm{~g} / \mathrm{ml}$ density (Amersham Biosciences, Inc., Piscataway, NJ, USA). DNA was isolated with the QIAamp DNA Blood Mini Kit (Qiagen, Hilden, Germany). Finally, DNA was eluted from the column with $60-70 \mu \mathrm{l}$ of elution buffer. The details of the chimerism analysis method were described in our previous publication [11].

Statistical analysis was performed using SPSS IBM Statistics (Version 24) and XLSTAT 2019 1.3. Non-parametric tests (Pearson's Chi-square, chi-square test with simulating $p$ values - test insensitive to small numbers, KruskalWallis) were used for group comparison. OS and EFS were estimated using Kaplan-Meier method and Log-rank tests. Cumulative incidence of relapse was performed using STATA. Statistical significance was considered $<0.05$.

The study was approved by the Ethics Committee of the Medical University of Lublin (KE-0254/70/2010).

\section{Results}

The median follow-up was 4.58 years ( $1.00-15.79$ years)

The 5-year overall survival (OS) and event-free survival (EFS) for the whole group of patients were 84 and $80 \%$, respectively. Further comparisons were performed in groups of children with complete chimerism (CC) and mixed chimerism (MC) assessed on days $+14,+21,+$ 28 . On day +7 all, but one patient presented MC, therefore statistical analyses were not performed for this time point. No statistical differences were found in OS and EFS in analysed time points. The results are presented on Figs. 1 and 2.

Analysis of early chimerism showed that the median donor chimerism level was $60 \%$ on day $+7,90 \%$ on day + $14,96 \%$ on day +21 , and $98 \%$ on day +28 . The kinetics of early chimerism in the studied group of patients is presented in Fig. 3.

We analysed factors, that may have influenced the status of early chimerism (Table 2). In our cohort of patients, the matched unrelated donor, male donor, number of transplanted CD34+ cells above $4.47 \times 10^{6} \mathrm{~kg}$ and no ATG serotherapy were statistically related to a higher level of donor chimerism. The immunophenotype of the disease, patient's age at HSCT, recipient's sex, stem cell source (peripheral blood/bone marrow) and conditioning regimen had no impact on early chimerism. 


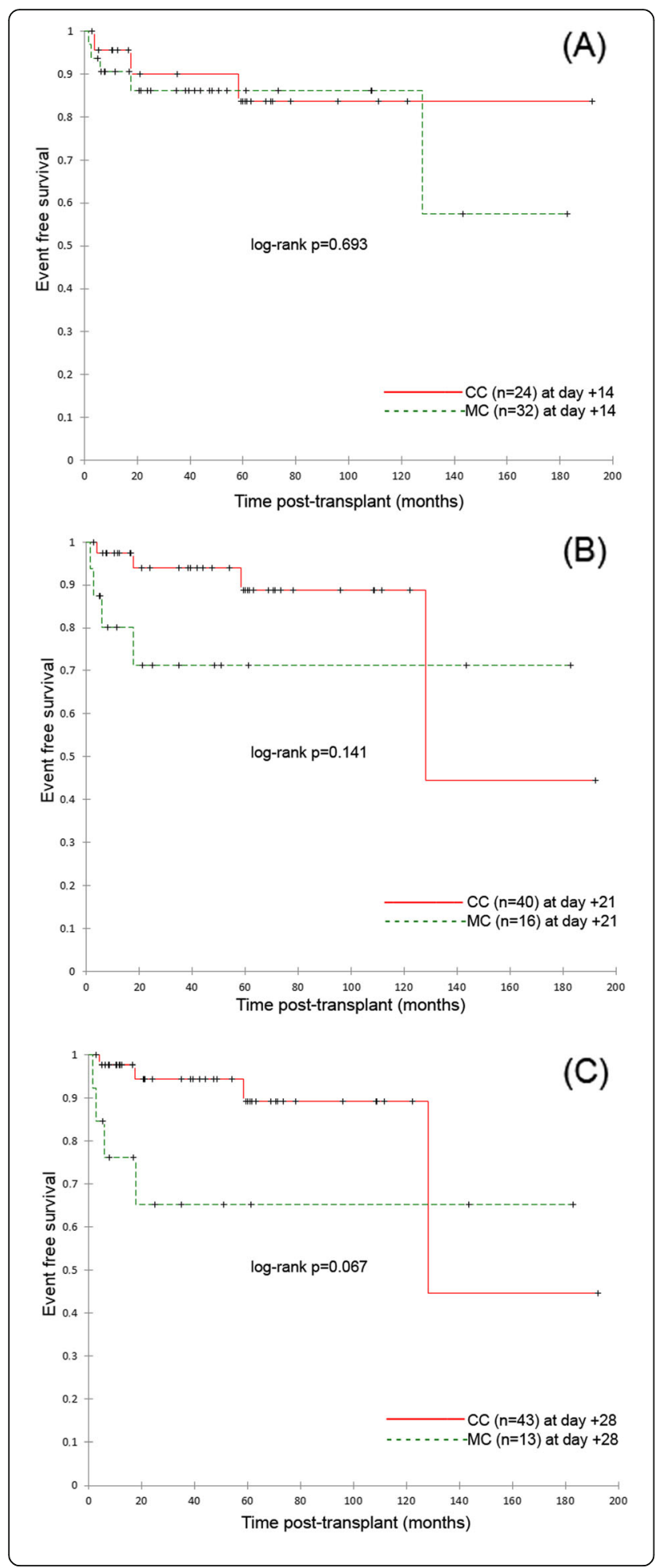

Fig. 2 The even free survive (EFS) of study patients. a Kaplan-Meier survival plots for EFS of study patients with complete donor chimerism $(n=24)$ in day 14 and patients with mixed chimerism $(n=32)$ in day 14. Study cohort: $n=56, p=0.693$. b Kaplan-Meier survival plots for EFS of study patients with complete donor chimerism $(n=40)$ in day 21 and patients with mixed chimerism $(n=16)$ in day 21. Study cohort: $n=56, p=0.141$. c Kaplan-Meier survival plots for EFS of study patients with complete donor chimerism $(n=43)$ in day 28 and patients with mixed chimerism $(n=13)$ in day 28. Study cohort: $n=56, p=0.067$

Acute graft versus host disease (aGvHD) grades II-IV was diagnosed in 23 patients. For statistical analyses of the effect of donor chimerism levels on aGvHD incidence, all patients were divided into two groups based on donor chimerism levels above and below $80 \%$. These values were determined on the basis of the fact that in the whole group of patients, the median percentage of donor chimerism before +28 days reached $80 \%$. No statistically significant effect of the level of donor chimerism above $80 \%$ achieved by patients before day +28 on the incidence of aGvHD was found $(p=0.22$ on day 7; $p=0.69$ on day $14 ; p=0.93$ on day $21 ; p=0.75$ on day 28). It was found that in all patients who developed aGvHD, the level of donor chimerism on day +7 was above $60 \%$.

The level of donor chimerism above $80 \%$ had no effect on chronic graft versus host disease (cGvHD) $(p=0.05$ on day $7 ; p=0.93$ on day $14 ; p=0.85$ on day $21 ; p=0.27$ on day 28$)$.

In two patients, increasing recipient chimerism was found on day +21 , and for that reason, the cyclosporine was discontinued. These children have achieved complete donor chimerism on days +40 and +90 , respectively. At the end of the observation period, both were alive and in complete remission 2.5 and 3.5 years, respectively, after HSCT with complete donor chimerism.

Forty-eight patients (86\%) were alive and in complete remission (in 45 patients, complete donor chimerism was found, while recipient haematopoiesis was detected in three patients). Eight patients (14\%) died. Relapse occurred in five of them (9\%) after day +28 , between 3 months and 4.5 years post-HSCT. All relapsed patients presented with increasing recipient chimerism (IMC) on days $+91,+93,+331,+444$, and +1285 , respectively. The relapse was diagnosed between 7 and 10 days after IMC was diagnosed. Three of the relapsed patients achieved complete donor chimerism early on day +14 . No difference in cumulative incidence (CI) of relapse was observed in patients with donor chimerism lower and higher than $60 \%$ on day + 7: CI (95\%) $0.114(0.031-$ $0.43)$ and $0.139(0.05-0.406)$ respectively $(p=0.56)$; as well as in CI of relapse in patients with $\mathrm{MC}$ and $\mathrm{CC}$ on day + 14, respectively: CI (95\%) $0.063(0.015-0.28)$ and 


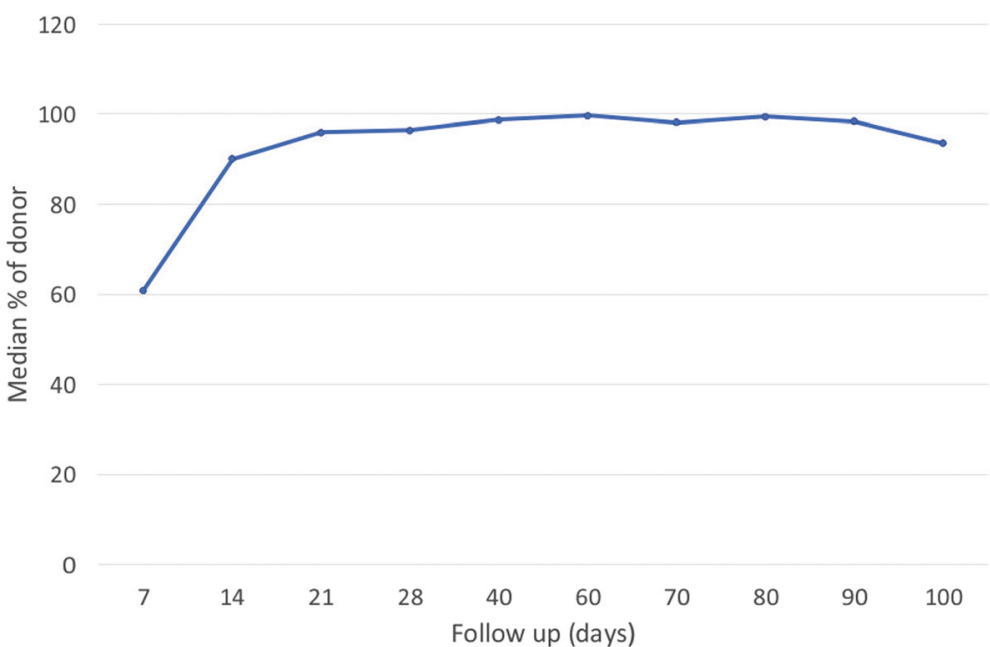

Fig. 3 The graph shows the kinetics of chimerism in all analysed patientsThe results presented on the curve are median (expressed as a percentage) values of donor cells in each time point on the schedule of monitoring chimerism

$0.161(0.061-0.461)$, respectively $(p=0.35)$. Three patients $(5 \%)$ died due to transplant-related complications.

\section{Discussion}

The literature data suggest, that chimerism analyses are routinely performed for the surveillance of engraftment. In recent years, these studies have become the basis for therapeutic intervention [13, 14]. Analysis of short tandem repeats used in our study, is described in the literature with the recommendations for current laboratory practice as the method for the post-transplant monitoring of donor engraftment [12, 15]. The previous literature data suggested that serial mixed chimerism analysis in patients with acute laeukemia at the short time intervals by PCR provides a reliable and rapid screening method for the early detection of relapse [16]. Based on its limited sensitivity to detect a minor cell population of approximately $1 \%$, monitoring of chimerism in the whole blood is not suitable to serve as the minimal residual disease (MRD) marker. For the assessment of MRD, other techniques should be used [17].

Relapse after transplantation is a major cause of treatment failure in paediatric patients with ALL. Barrios $\mathrm{M}$ et al. [18] presented results that indicate that constants assessments of chimerism allows the prediction of relapse and death after HSCT for acute leukaemia. In their study, patients with increasing mixed chimerism (IMC) showed a significantly higher $(p<$ 0.001 ) rate of relapse $(93.1 \%)$ and death $(89.7 \%)$ in comparison to both those with complete chimerism (CC) $(29.9 \%$ relapse, $44.1 \%$ dead) or decreasing MC (11.1\% relapse, $44.4 \%$ dead). Relapse was found in $39.8 \%$ of analysed patients [18]. The correlation between donor chimerism status and disease relapse after allo-HSCT was investigated by Jiang $\mathrm{Y}$ et al. [19]. They showed, that a total of $21.6 \%$ of patients had recurrent disease. In our analysed group, relapse was observed in $9 \%$ of patients who showed increasing recipient chimerism, although on day +14 , they were complete chimeras. Five-year OS and 5-year EFS were $62.07 \pm 4.37 \%$ and $56.17 \pm 4.38 \%$, respectively, for the overall cohort of patients with ALL in the Pachon $C$ et al. study [20]. In our study, OS (83\%) and EFS (84\%) were higher than those described in the literature [20]. Three of our patients are alive with stable mixed chimerism (10\% donor, 35\% donor and 90\% donor, respectively), which is in line with the observation of Levrat E. et al. with very long-term stability of MC in patients with haematologic malignancies [21].

Lassaletta A et al. [22] analysed chimerism by the day 30 after peripheral blood progenitor cell transplantation. A total of 27/39 patients showed $\mathrm{CC}$ by day 30 after HSCT, but the median time to achieve CC was 15 days (range $8-750$ ). In $15.4 \%$ of patients, CC was never achieved [22]. On the day +7 , a median of $61 \%$ of our patients presented very early complete donor chimerism, whereas on the day +14 , a median of $90 \%$ patients had complete donor chimerism. Finally, 48/56 (86\%) of our patients achieved complete donor chimerism.

Comparable to other studies, in our cohort no correlation between early donor chimerism and the source of stem cell transplantation was found, but the number of transplanted CD34+ cells had a significant impact on patients' chimerism status [22, 23]. We observed that matched unrelated and male donors were connected with high-level donor chimerism on days +7 and +14 , similar to other reports [24]. 
Table 2 Characteristics of factors influencing on the early chimerism status

\begin{tabular}{|c|c|c|c|c|c|c|c|c|}
\hline \multirow[t]{2}{*}{ Transplant variables } & \multicolumn{8}{|c|}{ Donor chimerism level (median \%) } \\
\hline & +7 day & $p$ value & +14 day & $p$ value & +21 day & $p$ value & +28 day & $p$ value \\
\hline \multicolumn{9}{|l|}{ Underlying diseases } \\
\hline B ALL $n=31$ & 58 & $p=0.9$ & 100 & $p=0.3$ & 100 & $p=0.79$ & 100 & $p=0.58$ \\
\hline TALL $n=25$ & 63 & & 95 & & 100 & & 100 & \\
\hline \multicolumn{9}{|l|}{ Age of patient } \\
\hline$<$ median (8.67 years) $n=28$ & 58 & $p=0.98$ & 95 & $p=0.66$ & 100 & $p=0.73$ & 100 & $p=0.86$ \\
\hline$>$ median ( 8.67 years) $n=28$ & 65 & & 99 & & 100 & & 100 & \\
\hline \multicolumn{9}{|l|}{ Patient gender } \\
\hline Male $n=38$ & 61 & $p=0.99$ & 94 & $p=0.15$ & 100 & $p=0.68$ & 100 & $p=0.7$ \\
\hline Female $n=18$ & 62 & & 100 & & 100 & & 100 & \\
\hline \multicolumn{9}{|l|}{ Donor type } \\
\hline Matched related $n=25$ & 49 & $p=0.06$ & 90 & $\underline{p}=0.02$ & 100 & & 100 & \\
\hline Matched unrelated $n=28$ & 68 & & 100 & & 100 & $\underline{p}=0.01$ & 100 & $\underline{p}=0.02$ \\
\hline Mismatched related $n=3$ & 80 & & 100 & & 100 & & 100 & \\
\hline \multicolumn{9}{|l|}{ Donor gender } \\
\hline Male $n=31$ & 77 & $\underline{p}=0.003$ & 100 & $\underline{p}=0.041$ & 100 & $p=0.56$ & 100 & $p=0.80$ \\
\hline Female $n=25$ & 46 & & 89 & & 100 & & 100 & \\
\hline \multicolumn{9}{|l|}{ Stem cell source } \\
\hline Bone marrow $n=47$ & 60 & $p=0.64$ & 96 & $p=0.20$ & 100 & $p=0.32$ & 100 & $p=0.19$ \\
\hline Peripheral blood $n=9$ & 63 & & 100 & & 100 & & 100 & \\
\hline \multicolumn{9}{|l|}{ Conditioning regimen } \\
\hline Radiation-based $n=41$ & 60 & $p=0.33$ & 96 & $p=0.40$ & 100 & $p=0.40$ & 100 & $p=0.43$ \\
\hline Busulfan-based $n=2$ & 74 & & 80 & & 85 & & 91 & \\
\hline Reduced toxicity $n=13$ & 67 & & 100 & & 100 & & 100 & \\
\hline \multicolumn{9}{|l|}{ Serotherapy (ATG) } \\
\hline YES $n=28$ & 49 & $\underline{p}=0.05$ & 94 & $p=0.11$ & 100 & $\underline{p}=0.016$ & 100 & $\underline{p}=0.023$ \\
\hline $\mathrm{NO} n=28$ & 68 & & 100 & & 100 & & 100 & \\
\hline \multicolumn{9}{|c|}{ Number of CD34+ cells (median 4,47) } \\
\hline$<4,47 \times 10^{6} n=35$ & 58 & $p=0.41$ & 94 & $\underline{p}=0.036$ & 100 & $p=0.08$ & 100 & $p=0.19$ \\
\hline$>4,47 \times 10^{6} n=21$ & 67 & & 100 & & 100 & & 100 & \\
\hline \multicolumn{9}{|l|}{ Patients } \\
\hline without event $n=48$ & 62 & $p=0.98$ & 68 & $p=0.48$ & 100 & $p=0.88$ & 100 & $p=0.56$ \\
\hline with relapse $n=5$ & 64 & & 97 & & 100 & & 100 & \\
\hline with TRM no relapse $n=3$ & 65 & & 81 & & 100 & & 100 & \\
\hline
\end{tabular}

B ALL B-cell acute lymphoblastic leukaemia, T ALL T-cell acute lymphoblastic leukaemia, ATG Anti-thymocyte globulin, TRM Transplant related mortality, $p=0.05$ this result is on the border of the statistical significance

According to Sakellarii I at al. study, the survival rates in matched transplants were promising at a relatively low-dose ATG as an effective prophylaxis for acute GvHD [25]. Our results indicate that ATG is also effective but connected to mixed chimerism in the very early period after HSCT. In patients who received ATG as GvHD prophylaxis, engraftment with complete donor chimerism was observed later than that in patients without ATG (day +21 vs +14 , respectively). The conditioning regimen (myeloablative) did not affect early chimerism status, which is compatible with other reports $[26,27]$.

Lassaletta et al. [22] presented results correlation between the chimerism status at +30 day and chronic GvHD. They observed, that the status of CC by day +30 after HSCT, was notably related to the development of chronic GvHD. Patients who presented CC by day +30 had statistically higher, probability of developing chronic GvHD, comparing to the patients with $\mathrm{MC}$ by day +30 [22]. Mossalam G et al. [26] observed that low donor 
chimerism in patients was connected with a reduced risk of the development chronic GvHD. Jaksch M et al. [28] noticed a significantly higher risk of aGvHD grades II-IV in patients with complete donor CD4+ T-cell chimerism on day 7 and patients who increased $50 \%$ or more in donor CD4+ T cells between days 7 and 10 after SCT. We did not observe a correlation between early donor chimerism and aGvHD or cGvHD, perhaps due to GvHD prophylaxis. The patients who developed cGvHD, presented donor chimerism above $80 \%$ on day $+7(p=0.05)$. To confirm this finding, the studies should be continued on a larger group of patients.

Horn B et al. [29] describe the long-term follow-up of children with acute laeukemia with early mixed chimerismbased post-transplant immunotherapy. Children receiving post-transplant immunotherapy had similar outcomes to patients achieving complete donor chimerism spontaneously. Rettinger E et al. added that the immunotherapy in the patients with mixed chimerism improves survival in childhood ALL and does not increase the risk of acute GvHD [30]. In our cohort, a successful therapeutic intervention was undertaken twice on the basis of chimerism measurements in the early post-transplant period $($ day +21$)$.

\section{Conclusions}

The data presented in this study provide a valuable input for the analysis of the significance of the very early assessment of chimerism in children with ALL treated with HSCT. Our findings suggest that early monitoring of chimerism after HSCT may be a helpful tool in predicting transplant rejection and using successful therapeutic intervention. This study has its limitations, such as no evaluation of the chimerism in lymphocyte subpopulations. Prospective observational studies and multicentre retrospective studies on larger groups of patients, including those diagnosed with different malignancies, would allow comparison of the results obtained for different groups of patients.

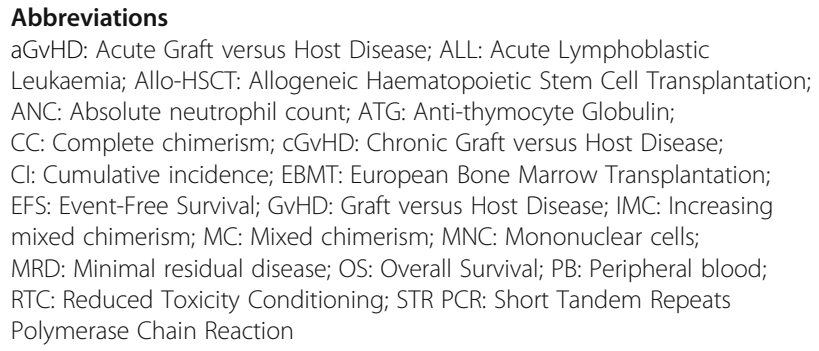

\section{Acknowledgements}

Not applicable.

\section{Authors' contribution}

$M L, A Z-P$ and $K D$ are responsible for the conception and design of the study. AZ-P, JZ, AM and DG shared patients' clinical data and peripheral blood samples. ML and AM conducted laboratory work. JZ and DG were responsible for the acquisition of literatures for manuscript. ML, AZ-P were responsible for interpretation of data. ML, KD and JRK prepared final manuscript for publication. The final manuscript was reviewed and approved by all authors.

Funding

No funding.

Availability of data and materials

Data and material are available upon request.

Agnieszka Zaucha-Prażmo e-mail agnieszkazauchaprazmo@umlub.pl

Ethics approval and consent to participate

The study was approved by the Ethics Committee of the Medical University of Lublin (KE-0254/70/2010).

All of participants have written consent to participate and publish the data. All procedures performed in studies involving human participants were in accordance with the ethical standards of the institutional and/or national research committee and with the 1964 Helsinki declaration and its later amendments or comparable ethical standards. Informed consent was obtained from all individuals included in the study and their parents or guardians on behalf of any participant under the age of 16 .

\section{Consent for publication}

Not applicable.

\section{Competing interests}

The authors declare that they have no competing interests.

\section{Author details}

'Laboratory of Genetic Diagnostics, Department of Pediatric Hematology, Oncology, and Transplantology, Medical University of Lublin, A. Gebali 6, 20-093 Lublin, Poland. 'Department of Pediatric Hematology, Oncology, and Transplantology, Medical University of Lublin, A. Gebali 6, 20-093 Lublin, Poland.

Received: 11 August 2019 Accepted: 12 November 2019

Published online: 26 November 2019

\section{References}

1. Schrappe M, Hunger SP, Pui CH, Saha V, Gaynon PS, Baruchel A, et al. Outcomes after induction failure in childhood acute lymphoblastic leukemia. N Engl J Med. 2012;366:1371-81. https://doi.org/10.1056/ NEJMoa1110169.

2. Wachowiak J, Chybicka A, Kowalczyk JR, Wysocki M, Goździk J, Gorczyńska E, Kałwak K, Styczyński J, Drabko K, Pieczonka A. Development and current use of in hematopoietic stem cell transplantation in children and adolescents in Poland: Report of the Polish pediatric study group for hematopoietic stem cell transplantation of the Polish society for pediatric oncology and hematology. Transfus Apher Sci. 2018. https://doi.org/10.1016/j.transci.2018.05.012.

3. Sung PH, Im C, Hyun SY, Shim KY, Ji L, Kong JH. Unusual isolated extramedullary relapse of acute lymphoblastic leukemia in the breast despite complete donor hematopoietic chimerism after allogeneic hematopoietic stem cell transplantation. Korean J Intern Med. 2018;33:21820. https://doi.org/10.3904/kjim.2015.089.

4. Bader P, Niethammer D, Willasch A, Kreyenberg H, Klingebiel T. How and when should we monitor chimerism after allogenic stem cell transplantation? Bone Marrow Transplant. 2005;35:107-19. https://doi.org/10 1038/sj.bmt.1704715.

5. Breuer S, Preuner S, Fritsch G, Daxberger H, Koenig M, Poetschger U, et al. Early recipient chimerism testing in the T- and NK-cell lineages for risk assessment of graft rejection in pediatric patients undergoing allogeneic stem cell transplantation. Leukemia. 2012;26:509-19. https://doi.org/10.1038/ leu.2011.244.

6. Stahl T, Böhme MU, Kröger N, Fehse B. Digital PCR to assess hematopoietic chimerism after allogeneic stem cell transplantation. Exp Hematol. 2015;43: 462-8. https://doi.org/10.1016/j.exphem.2015.02.006.

7. Chia WC, Khoo TS, Wahid SFSA, Razak NFA, Alauddin H, Sabudin RZAR, Othman A, Hassan R, Hussin NH. Multiplex PCR panel for assessment of chimerism following hematopoietic stem cell transplantation (HSCT). Ann Hematol. 2019;98:1279-91. https://doi.org/10.1007/s00277-019-03626-w. 
8. Lion T. Molecular monitoring after HSCT. Chimerism. In: Apperley J, Carreras E, Gluckman E, Masszi T, editors. The EBMT Handbook, vol. 16.2; 2012. p. 281-7. https://ebmtonline.forumservice.net/media/16_2/tex/content_alt/ EBMT_Handbook2012_CHAP16_2.pdf.

9. Bader P. Documentation of Engraftment and Chimerism After HSCT. In: Carreras E, Dufour C, Mohty M, Kröger N, editors. The EBMT Handbook Springer, vol. 72. Cham; 2019. p. 539-45. https://doi.org/10.1007/978-3-03002278-5_20.

10. Apperley J, Carreras E, Gluckman E, Gratwohl A, Masszi T. Principles of conditioning. In: Apperley J, Carreras E, Gluckman E, Masszi T, editors. Haematopoietic stem cell transplantation. Genoa: Forum Service Editore; 2008. p. 128-44.

11. Lejman M, Drabko K, Styka B, Winnicka D, Babicz M, Jaszczuk I, Kowalczyk JR. Usefulness of post-transplant hematopoietic chimera monitoring by use of the quantitative fluorescence polymerase chain reaction method. Transplant Proc. 2017. PMID: 28923646;49:1903-10. https://doi.org/10.1016/j. transproceed.2017.04.013.

12. Lion $T$, Watzinger $F$, Preuner $S$, Kreyenberg $H$, Tilanus $M$, de Weger $R$, Lion $T$, Watzinger F, Preuner S, Kreyenberg $H$, Tilanus $M$, de Weger $R$, et al. The EuroChimerism concept for a standardized approach to chimeras analysis after allogeneic stem cell transplantation. Leukemia. 2012;26:1821-8. https:// doi.org/10.1038/leu.2012.66.

13. Bader $P$, Kreyenberg $H$, Hoelle $W$, Dueckers $G$, Handgretinger $R$, Lang $P$, et al. Increasing mixed Chimerism is an important prognostic factor for unfavorable outcome in children with acute lymphoblastic Leucemia after allogeneic stem cell transplantation: possible role for pre-Emptive immunotherapy? J Clin Oncol. 2004;22:1696-706.

14. Qin XY, Li GX, Qin YZ, Wang Y, Wang FR, Liu DH, et al. Quantitative chimerism: an independent acute leukemia prognosis indicator following allogeneic hematopoietic SCT. Bone Marrow Transplant. 2014;49:1269-77. https://doi.org/10.1038/bmt.2014.158.

15. Clark JR, Scott SD, Jack AL, Lee H, Mason J, Carter Gl, et al. Monitoring of chimeras following allogeneic haematopoietic stem cell transplantation (HSCT): technical recommendations for the use of short tandem repeat (STR) based techniques, on behalf of the United Kingdom National External Quality Assessment Service for leucocyte Immunophenotyping Chimerism working group. Br J Haematol. 2015; 168:26-37. https://doi.org/10.1111/bjh.13073.

16. Bader $P$, Beck J, Frey A, Schlegel PG, Hebarth $H$, Handgretinger $R$, et al. Serial and quantitative analysis of mixed hematopoietic chimerism by PCR in patients with acute leukemias allows the prediction of relapse after allogeneic BMT. Bone Marrow Transplant. 1998;21:487-95. https://doi.org/10. 1038/sj.bmt.1701119.

17. Preuner S, Peters C, Pötschger U, Daxberger H, Fritsch G, Gryeregger R, et al. Risk assessment of relapse by lineage-specific monitoring of chimerism in children undergoing allogeneic stem cell transplantation for acute lymphoblastic leukemia. Haematologica. 2016;101:741-6. https://doi.org/10. 3324/haematol.2015.135137.

18. Barrios M, Jimenez-Velasco A, Roman-Gomez J, Madrigal ME, Castillejo JA, Torres A, et al. Chimerism status is a useful predictor of relapse after allogeneic stem cell transplantation for acute leukemia. Haematologica. 2003;88:801-10.

19. Jiang $Y$, Wan L, Qin Y, Yan X, Xie K, Wang C. Donor Chimerism of B Cells and Natural Killer Cells Provides Useful Information to predict Hematologic Relapse following Allogeneic Hematopoietic Stem Cell Transplantation. PLoS One. 2015;10(7):1-10. https://doi.org/10.1371/journal.pone.0133671.

20. Pachon C, Oger E, Michel G, Dalle JH, Salmon A, Nalken B, et al. Follow-up of post -transplanta minimal residual disease and chimerism in childhood lymphoblastic leukaemia: 90 d to react. Br J Haematol. 2015;169:249-61. https://doi.org/10.1111/bjh.13272.

21. Levrat E, Roosnek E, Masouridi S, Mohty B, Ansari M, Villard J, et al. Very long term stability of mixed Chimerism after allogeneic hematopoietic stem cell transplantation in patients with hematologic malignancies. Bone Marrow Res. 2015. https://doi.org/10.1155/2015/176526.

22. Lassaletta A, Ramirez M, Montero JM, et al. Full donor chimerism by day 30 after allogeneic peripheral blood progenitor cell transplantation is associated with a low risk of relapse in pediatric patients with hematological malignancies. Bone Marrow Transplant. 2005;19:504-6. https://doi.org/10.1038/sj.leu.2403692.

23. Chen CT, Gau JP, Liu JH, Chiou TJ, Hsiao LT, Liu YC. Early achievement of full donor chimerism after allogeneic hematopoietic stem cell transplantation predicts lower relapse risk in patients with acute lymphoblastic leukemia. J Chin Med Assoc. 2018;81:1038-43. https://doi.org/10.1016/j.jcma.2018.06.005.

24. Faraci M, Bognasco F, Leoni M, Giardino S, Terranova P, Subissi L, Di Duca M, Di Martino D, Lanino E. Evaluation of chimerism dynamics after allogeneic hematopoietic stem cell transplantation in children with nonmalignant diseases. Biol Blood Marrow Transplant. 2018;24:1088-102. https://doi.org/10.1016/j.bbmt.2017.12.801.

25. Sakellarii I, Batsis I, Bousiou Z, Mallouri D, Constantinou V, Gavriilaki E, et al, The role of low-dose anti-thymocyte globulin as standard prophylaxis in mismatched and matched unrelated hematopoietic peripheral stem cell transplantation for hematologic malignancies. Clin Lymphoma Myeloma Leuk. 2017;17:658-66. https://doi.org/10.1016/j.clml 2017.06.008.

26. Mossallam G, Kamel AM, Storer B, Martin PJ. Prognostic utility of routine Chimerism testing at 2-6 months after allogeneic hematopoietic stem cell transplantation. Biol Blood Marrow Transplant. 2009:15:352-9.

27. Doney KC, Loken MR, Bryant EM, et al. Lack of utility of chimerism studies obtained 2-3 months after myeloablative hematopoietic cell transplantation for ALL. Bone Marrow Transplant. 2008;42:271-4.

28. Jaksch M, Uzunel M, Remberger M, Sundberg B, Mattsson J. Molecular monitoring of T-cell chimerism early after allogeneic stem cell transplantation may predict the occurrence of acute GVHD grades II-IV. Clin Transpl. 2005;19:346-9. https://doi.org/10.1111/j.1399-0012.2005.00345.x.

29. Horn B, Wahlstrom JT, Melton A, Liou A, Ouachee-Chardin M, Sunkersett G, et al. Early mixed chimerism-based preemptive immunotherapy in children undergoing allogeneic hematopoietic stem cell transplantation for acute leukemia. Pediatr Blood Cancer. 2017;64:1-5. https://doi.org/10.1002/pbc.26464

30. Rettinger E, Merker M, Salzmann-Manrique E, Kreyenberg H, Krenn T, Dürken $\mathrm{M}$, et al. Pre-Emptive immunotherapy for clearance of molecular disease in childhood acute lymphoblastic leukemia after transplantation. Biol Blood Marrow Transplant. 2017;23:87-95. https://doi.org/10.1016/j.bbmt.2016.10.006.

\section{Publisher's Note}

Springer Nature remains neutral with regard to jurisdictional claims in published maps and institutional affiliations.
Ready to submit your research? Choose BMC and benefit from:

- fast, convenient online submission

- thorough peer review by experienced researchers in your field

- rapid publication on acceptance

- support for research data, including large and complex data types

- gold Open Access which fosters wider collaboration and increased citations

- maximum visibility for your research: over $100 \mathrm{M}$ website views per year

At $\mathrm{BMC}$, research is always in progress.

Learn more biomedcentral.com/submissions 